\title{
COGNITIVE SCIENCES AND HUMAN DEVELOPMENT
}

\section{Exploring Managers' Perspective on Factors Affecting Generation Y Retention}

\author{
Dideana Thompson \& Agatha Lamentan Muda* \\ Faculty of Cognitive Sciences and Human Development, \\ Universiti Malaysia Sarawak, 94300 Kota Samarahan, Sarawak, Malaysia
}

\begin{abstract}
The study explores factors behind Generation Y employees' retention from the perspective of managers in a financial services sector. A qualitative method was employed, by interviewing eight managers as informants. The results show ten factors affecting Generation Y employees' retention are compensation and pay, personal development, job security, job satisfaction, work-life balance, reward and recognition, training, leadership, relationship and communication, and work environment. Seven main challenges to retain Generation $\mathrm{Y}$ employees identified are loyalty, their love for a challenging job, communication, strategy, working style, satisfaction, and traits. The study discusses implications and suggestions for organisational level strategies to retain Generation Y employees.
\end{abstract}

Keywords: employee retention, generation Y

ARTICLE INFO

Email address: malamentan@unimas.my (Agatha Lamentan Muda)

*Corresponding author

https://doi.org/10.33736/jcshd.3798.2021

e-ISSN: 2550-1623

Manuscript received: 11 August 2021; Accepted: 15 September 2021; Date of publication: 25 September 2021

Copyright: This is an open-access article distributed under the terms of the CC-BY-NC-SA (Creative Commons Attribution-NonCommercial-ShareAlike 4.0 International License), which permits unrestricted use, distribution, and reproduction in any medium, for non-commercial purposes, provided the original work of the author(s) is properly cited. 


\section{INTRODUCTION}

In today's scenario, employee retention is considered a vital concept and has grown to be a top priority for organisations and managers. For an organisation to accomplish its long-term goals, it must have the ability and capability to encourage and retain key employees. Organisations and managers believe that retaining competent employees would ensure their organisation reach its long-term goals and improves flexibility in an ever-demanding industry. The attempt to retain productive employees is equally important as recruiting and selecting the best candidates to occupy the vacant position in the organisation. Hence, this study examines factors affecting employee retention among Generation $\mathrm{Y}$ in the financial services industry.

Compared to the competitive nature of business or organisation, a non-competitive environment is less likely to experience such a situation as many qualified candidates are waiting to fill up the position whenever an employee quit his or her job. However, in a more market environment setting that is more competitive, the retention of human resources is far more crucial as certain job roles require specific or unique skill sets, expertise, and experiences that few employees have in an organisation (Kalali, 2015). Attaining, developing, and retaining competent employees is a crucial objective that human resource management practices have aimed to accomplish in the past twenty years (Pittino, Visintin, Lenger, \& Sternad, 2016). An organisation that fails to retain highperforming employees loses their capability to stay competitive in its nature of business. These employees have moved to other organisations that benefit the employee's new workplace (Stirpe \& Zárraga-Oberty, 2017). This failure to retain high performing or well-trained employees that led to turnover creates a vacuum in the organisation. It could impact productivity and how well the other employees perform (Lavanya, 2017). Past research has shown that many factors influence employee retention and morale, including effective communication, employee recognition, and an environment that inspires learning, creativity, innovation, and flexibility (Beck, 2005; Evans \& Kaye, 2003; Rice, 2005).

According to Zainee and Puteh (2020), several studies have identified Generation Y as a new growing talents wave in the labour market. Being the new group of the labour force, Generation Y poses distinctive characteristics than Generation X and Baby Boomers (Fadilah, Maniam, \& Nafis, 2015). Unlike previous generations, Generation Y individuals are very demanding, have strong bargaining power, and have a very influential workforce. A past study also found that Generation $\mathrm{Y}$ is disloyal toward its organisations, contributing to a high turnover rate (Fadilah, Maniam, \& Nafis, 2015). The high turnover rate stemming from Generation Y employees has been the concern of HR managers within the Asia Pacific region. Malaysia is among the countries highlighting this issue in its major mass media. The Malaysian managers expressed their HR practitioners' concerns that the turnover among this group is becoming increasingly prevalent. The combination of Generation Y with Generation X and the older generations in the workplace creates challenges for HR managers, as their characteristics are markedly different. The attitudes and characteristics of the Generation $\mathrm{Y}$ in particular set them apart from the other generations and thus creates new challenges for the Human Resource Management. To be successful in the future, it will be critical for organisations and managers to understand these employees. With the high number of turnovers 
coming from Generation Y, it is critical for managers in identifying the root of the problem as well as crucial factors that influence their retention. This study looks at the managers' views on retention factors of their Generation Y employees in the context of Malaysian financial services organisations. It aims to update the current understanding of retention management as it is worked out in practice by the managers. The researchers want to ascertain whether the retention factors considered in the literature correspond with those factors viewed as necessary by the managers. Their ever-increasing representation in the workforce marks the rationale for focusing on Generation Y employees.

\section{PROBLEM STATEMENT}

Many past studies have shown the direct causal relationship between human resource practices and employee retention (Idris, 2014, Karve \& Dias, 2016, Kossivi, Xu \& Kalgora, 2016, Baharin $\&$ Wan Hanafi, 2018). The presence of different generations in the organisations has been underemphasised since many past studies focused on employees. Researchers should not deny that the co-existence of employees from different generations in the workplace have also made employee retention more complex (Rani \& Samuel, 2016). Additionally, the characteristics of the predecessor generations of Baby Boomers and Generation $\mathrm{X}$ were loyal to their organisation; consequently, their retention rate was high. On the opposite, Generation Y showed a distinct characteristic where a job change among this generation is done every two years. They change their careers as many as seven times in their working life (Meuse \& Mlodzik, 2010), thus demonstrating low employee retention. It is a concern as Generation $\mathrm{Y}$ is the highest number among employees to leave the organisation, by sixty per cent (Wiggins, 2016).

In addition, several surveys have reported that Generation Y employees in the Asia Pacific region have the shortest job tenure compared to other generational workforces. They have eighteen months of average job tenure compared to four years for the other generational workforces (Sheahan, 2008). The issue of the increased job mobility among Generation Y employees is not only problematic to the organisational effectiveness in terms of the incurred financial and nonfinancial costs associated with a high turnover rate, but more importantly, giving risk to the economic growth of the country in several diverse ways (Queiri, Yusoff \& Dwaikat, 2015). It is essential to identify strategies to retain Generation Y employees as they have the talent and criteria needed to meet the organisation's performance benchmark (Zee \& Yuk, 2016). Given the issue of Generation Y employee's retention, with its detrimental consequences on organisational effectiveness, thus the outcomes of this research are crucial as it reveals factors that contribute to Generation Y employees' retention in Malaysia from the perspective of managers.

Moreover, through this research, we will understand others exploring factors that are not common and less explored by past studies that could influence employee retention. It is a substantial element to be looked through seriously. The organisation and their managers could determine the challenges and improve their strategies to deal with the issue, particularly Generation $Y$ employees. This study pays a specific focus on the financial services industry. There are a few studies involving Generation $\mathrm{Y}$ and employee retention in various disciplines and contexts. 
However, studies on the financial services industry in Malaysia are scarce (Zainee \& Puteh, 2020). In 2017, according to the Emerald Insight database, less than 400 academic articles about employee retention in Malaysian settings were published. However, there are only a few studies on the financial services industry.

\section{RESEARCH OBJECTIVE}

3.1 To explore managers' perspectives on factors affecting Generation Y employees' retention.

3.2 To investigate challenges faced by organisations to retain Generation Y employees.

\section{LITERATURE REVIEW}

\subsection{Employee Retention}

Employee retention is a method whereby the organisation could understand and satisfy the employee's needs for the employee to stay, which then would help the organisation to achieve its strategic goal. Employee retention is valuable not only for the organisation but also to the employee. Hiring and retaining good employees have become the main concerns of every organisation in every industry. Retention is crucial because of severe competition among employers for competent employees. The fierce competition for competent employees results from several workplace trends, including a robust economy. Kossivi, Xu and Kalgora (2016) stated that workforce in the organisation can be differentiated into three-level which is the employee, managers and directors and different type of retention strategy need and can be applied to these level as different job task and different requirement are being conducted by these individuals daily.

In the late 1990s, Fitz-enz (1990) mentioned that employee loyalty and retention could not be judged by a sole issue but by a group of factors. Massive efforts had been made in an organisation that would prevent an employee from leaving. Nowadays, high rewards and benefits are no longer solely a significant factor preventing employees from leaving the organisation as many contributing factors could play a crucial role in retention strategy. Besides, Das and Baruah (2013) revealed that several factors influence employee's retention. In previous research, there are several numbers of factors related to employee retention have been discovered. Factors frequently mentioned comprise compensation, social support, career development, training and development, work environment and work-life balance, and a leadership style.

According to Irshad and Afridi (2007), the factors affecting employee retention are categorised into two groups: an organisational factor and a human resource factor. Organisational factors consist of social support, work environment, and leadership style while human resource factor consists of compensation, training and development, work-life balance, and career development opportunities. Meanwhile, Azeez (2017) claimed that human resource practices lead to employee 
retention. Compensation, training and development, work-life balance, and career development opportunities are the human resource factors stated by the author in his study. Azeez (2017) also mentioned that the organisation could improve their employee retention if their management improve their human resource practices.

Dwomoh and Frempong (2017) identified eight retention factors: an opportunity for career development, organisational environment, work-life balance, level of compensation, supervisors support, organisational justice, job security, and organisational values and beliefs. Aguenza and Som (2012) claimed that the factors of motivation that are vital in affecting the retention of employees are recognition, work-life balance, job characteristics, management, financial rewards, and career development. A study conducted by Lee and Sharbarwal (2014) mentioned that failure to pay a fair salary might affect employee satisfaction, leading to employee turnover. While Falahat, Gee and Liew (2019) stated that job enrichment, job pressure, and working environment could affect job satisfaction, influencing employee retention. Roy (2018) noted that opportunities are given in career development, and training and development impact employee retention. Lobburi (2012) revealed that perceived social support from supervisors, co-workers, and family and friends and perceived organisational support policy, such as fairness rewards, participation in decision-making and growth opportunities, were positively influenced to retention plan. Salahuddin (2010) stated that effective leadership style in the organisation affecting organisation success and employee retention.

\subsection{Generation Y Employees}

Today's workforce is characterised by different generational mentalities and priorities, conflicting work ethics, different values, and idiosyncratic styles. Organisations must understand the needs, expectations, and work preferences of multi-generations. The literature highlights three generations at the workplace, Boomers (1946-1960), Generation X (1961-1980), and Generation Y or Millennials (1981-2000) (Cennamo \& Gardner, 2011). Generation Y or the Millennials is the fastest growing workforce, also known as the digital generation. In terms of characteristics, they are passionate, self-reliant, independent and prefer to work as a team (Shih \& Allen, 2007). Generation $\mathrm{Y}$ has grown up in a technology-intensive environment and poses more adaptable technological skills than other generations (Cennamo \& Gardner, 2011). Moreover, Generation Y employees have job expectations regarding job characteristics, choosing employers, and achievements for their future careers. Generation Y has higher expectations for career development and is ambitious to seek career opportunities within the organisations. They want to enhance their skills and knowledge to remain in the talent market.

Generation Y employees seek career opportunities; otherwise, they prefer to leave the organisation and seek new opportunities (Cennamo \& Gardner, 2011). Moreover, Generation Y employees prefer challenging works to enhance their skills and abilities (Naim \& Lenka, 2018). Also, Generation $\mathrm{Y}$ has valuable expectations for work-life balance, mentoring, and career development. Thus, by offering these career enhancement opportunities, providing immediate feedback on performance, organisations can develop, maintain, and retain Generation Y employees (De Hauw 
\& De Vos, 2010). With differential needs and preferential of the employees in an organisation together with the shift of the younger employment force, companies are changing their policies, finding new strategies, work habits and a different attitude that need to be incorporated into the existing culture to tap their strengths and manage the new challenges ahead.

\subsection{Social Exchange Theory}

When an organisation treats their employees fairly and fully supports its employees, most employees are satisfied and willing to keep working in that same organisation. This situation is known as the social exchange theory. Cronpanzano and Mitchell (2005) stated that several social exchange relationships occur between employees based on this theory. Wayne, Shore and Liden (1997) also mentioned that excellent social exchange could make employees feel that they belong to or in the organisation. Moreover, employee intention to leave the organisation is low when the social exchange between employee-employer is achieved (Nawaz \& Pangil, 2016). Based on a study conducted by Abubakar, Chauhan and Kura (2015), the employee tends to stay at their current job position and organisation if they are satisfied with the organisation's rewards and benefits. Besides, the employee who perceives more outstanding organisational support has a high possibility to remain in the organisation (Eisenberger, Stinglhamber, Vandenberghe, Sucharski \& Rhoades, 2002; Allen, Shore, \& Griffeth, 2003). Therefore, based on this theory, organisations and managers should provide organisational support to enhance the character and behaviour of the employee. It would lead to high commitment, job satisfaction, and performance when the organisation feels valued and supported.

\section{METHODOLOGY}

This research uses a qualitative design to collect data by interviewing the informants to explore employee retention factors. In this study, the purposive sampling method in selecting the informants is used by the researchers. This strategy allows researchers to gather appropriate information from the relevant person to fulfil the research objectives. Eight managers of a financial services organisation are interviewed to obtain the needed information on factors affecting Generation Y retention. The specific criteria are a current or former manager with five to ten years of experience in the organisation. There are two male informants and six female informants at the age of 39 to 52 years old and have been working with the organisation for between five to ten years.

Four types of questions the informants are a) warming up questions; b) demographics questions; c) main questions on factors related to retention; and d) closing questions. The key topics or themes and the interview questions on the retention factors are developed based on past studies. Factors that appear the most frequent in the past studies are taken to see if they exist from the informants' perspective. These factors are compensation and pay, personal development, job security, job satisfaction, work-life balance, reward and recognition, training, leadership, relationship and communication, and work environment. These factors are then being separated into two; external 
and internal factors. A pilot study was conducted to test the validity of the questions and ensure the informants understood the questions.

The data collected from the informants through the interview process are gathered, analysed, and coded by using NVivo software. The data analysis for this research is done using thematic analysis. Thematic analysis is a method to dissect the data by classifying, organising, and providing insight towards the theme across the data gathered. This method allows the meaning and the experiences to be capture collectively (Braun \& Clarke, 2012). Qualitative data can be coded either by manual coding or automated coding. In this study, researchers used NVivo - a software specifically created for qualitative research. The following steps are done to analyse and code the data into meaningful data and group accordingly into various categories:

1. Compile the data from the answers given by informants during the interview.

2. Categorise the data by creating groups or categories of themes.

3. Recombine the data by placing relevant data according to the theme that it represents.

4. Understand and interpret the data into meaningful data to meet the research objective.

\section{FINDING AND DISCUSSION}

\subsection{Managers' Perspective on Factors Affecting Generation Y Employees Retention}

The data analysed found ten factors affecting employee retention based on the data gathered through the informants, which are the managers. These factors are compensation and pay, personal development, job security, job satisfaction, work-life balance, reward and recognition, training, leadership, relationship and communication, and work environment. Table 1 below indicates the responses by informants on factors affecting Generation Y employees' retention. These ten factors are divided into external and internal factors. The external factor here means that any external factor affecting the employee causes them to stay in the organisation. The external factor can be in physical form or tangible provided to the employee (Bergmann \& Scarpello, 2012) or, in short, a factor that comes not from the employee (AL-Muslawi \& Hamid, 2019).

On the other hand, internal factor means any internally affecting aspect that causes an employee to stay within the organisation. It means that the factor stems from the employee themselves as a factor they think may satisfy or fulfil their needs with the external factor. It can be seen more as intangible or not in the physical form (Hafiza, Shah, \& Jamsheed, 2011). The result of the research found that the external factor appears more than the internal factor, showing that the employee in the organisation of study favours external factors compared to internal factors. Emphasising the external factor, the factor of "reward and recognition" were the most stated factor by the informants that they felt was an essential and effective factor to retain the talent in the organisation. The following are some of the informants' answers regarding "reward and recognition" during the interview: 
"Gen Y are not loyal, these Gen tend to move for a better benefit."

"So far in this organisation I see they are more toward monetary reward such as bonus and token of appreciation."

"If they feel the company does not reward or recognised their effort they will move to other organisation."

It illustrates that the study's findings support the outcome of an earlier study that highlighted recognition along with the benefits, which is that reward is a tool for the employees to be motivated. With the motivation gained from it, the tendency for the employees to stay in the organisation is high (Mngomezulu, Challenor, Munapo, Mashau \& Chikandiwa 2015). Nevertheless, we note that the factor may be different in other organisation and across generation but focusing on the nature of the organisation of study which is in the financial services industry, rewards and recognition seem to be typical as the nature of this industry enable the employee to have their targets and goals. In return, they will get rewards which may be in the form of recognition and monetary. In addition, job security and training are the second most stated retention factors. According to informants, when the organisation provides job security to employees, they are happier to work. The findings supported a study by Majid, Samsudin, Noorkhizan, Noor and Zuffri (2017). In return to the job security provided by the organisation comes employees' loyalty which leads to employee's retention. From the interview also, it is found that Generation $\mathrm{Y}$ is much more eager to go for training followed by Generation X. As the training is provided to employees, they feel that they are learning and has gained a lot of new knowledge, which helps them to conduct their daily task. As this happened, the employees felt that the organisation was taking care of them and making them better at their job, and it became the factor for these employees to stay at the company. With supportive management, it increases the tendency for these employees to attach more to the organisation. This shows that the findings of this research support the outcome of the past study on the influences of training on employee's retention (Afroz, 2018, Chepkosgey, Namusonge, \& Makokha, 2019). The following are some of the informants' answers regarding "job security" and "training" during the interview:

"They do not have to find a new job so having a job that provide them job security, they felt blessed."

"They will stay in the organisation. The training indirectly helps along their personal development."

The social exchange theory that serves as a reference for this research appears to align with research findings. An employee's intention to leave the organisation is low when the social exchange between employee and employer is achieved (Nawaz \& Pangil, 2016). The exchange of social aspect between employee-employer mentioned rewards as it contains a positive value that 
brings satisfaction towards an employee. They are giving back to the organisation by staying in it and helping them with their skills and ability.

Table 1. Responses by informants on factors affecting Generation Y employees' retention

\begin{tabular}{ll}
\hline Informant & Factors \\
\hline 1 & Compensation and Pay, Personal Development, Job Security \\
\hline 2 & Job Satisfaction, Work-Life Balance, Work Environment \\
\hline 3 & $\begin{array}{l}\text { Rewards and Recognition, Training, Relationship and } \\
\text { Communication, Leadership }\end{array}$ \\
\hline 4 & Reward and Recognition, Job Security, Training \\
\hline 5 & Compensation and Pay, Reward and Recognition \\
\hline 6 & Reward and Recognition, Training \\
\hline 8 & Job Security, Reward and Recognition, Training \\
\hline
\end{tabular}

\subsection{Challenges faced by an organisation to retain Generation $Y$ employees in a selected financial services organisation}

Regarding challenges to retaining Generation $\mathrm{Y}$ employees, seven sub-codes are identified: loyalty, love for a challenging job, communication, strategy, working style, satisfaction, and traits. Emphasising loyalty as one of the challenges, Generation $\mathrm{Y}$ is hard to maintain their loyalty to the organisation. They will jump to another company if they feel that their needs are not fulfilled. In addition, their working styles are also different from the other generation as these Generation Y do enjoy more flexibility when working, and they are not fond of the micromanaging style of leadership. Furthermore, challenges at work have also become an issue with retaining this Generation Y. When they feel that the things, they are doing are routine and not challenging enough, they tend to move to another company. The findings supported a past study that described Generation $\mathrm{Y}$ as mobile, impatient, enjoy life through work, need fast progression in their career, demanding which makes them vulnerable and have higher tendency to leave their organisation and change jobs (Hurst \& Good, 2009; Simoneaux \& Stroud, 2010; Kaliannan \& Ponnusamy, 2016). The following are some of the informants' answers regarding the challenges faced by their organisation to retain Generation Y employees:

"They like more challenges; they are interested to join the company as they need challenges and not repetitive work."

"Minimal supervision then they are satisfied."

"They are eager to learn, they are easy to train, they are passionate about everything." 


\section{IMPLICATION, RECOMMENDATION AND CONCLUSION}

Past research on various generations or comparisons among generations are vastly done but mostly are general. This research intends to deepen and understand Generation Y employees' wants and needs, particularly in the financial services industry. This research brings timely implications to cope with Generation Y employees' turnover retention rate that is currently occurring in Malaysia. The study also focuses on extrinsic rewards and recognition, and how they critically matter for Generation Y employees to cope with rising prices, expected lifestyle and future obligations. Consequently, the management that wishes to retain Generation Y employees should acknowledge the needs of this group extrinsically. However, such decisions may incur additional financial resources that may not be available to most organisations.

Moreover, organisations should be receptive to the generational characteristics of Generation $\mathrm{Y}$ employees and tailor their HR strategies accordingly, as the one-size-fits-all approach is losing its relevance. Based on the findings of this research, job security and training are among the retention factors of Generation Y employees. Therefore, organisations must emphasise on competency development of Generation Y employees as a viable strategy to strengthen their engagement, commitment, and retention. The perception of learning and competency development in Generation Y employees will give them greater assurance of a more profitable future with the organisation. It would, in turn, result in positive psychological responses, including attachment and commitment leading to intention to stay forth.

In general, the present study has significant implications that extend to both industry and academia. This study contributes to the existing literature on retention and its linkage with Generation Y. In addition, another notable aspect is that based on findings of this research, Generation Y employee's retentions are linked to factors like compensation and pay, personal development, job security, job satisfaction, work-life balance, reward and recognition, training, leadership, relationship and communication, and work environment. From a managerial standpoint, the study provides a holistic view of the retention of Generation Y talent. Managers gain insights on Generation Y needs and motivators, which improves their understanding of how members of Generation Y are

different from other cohorts. It provides valuable information to assist HR managers in fine-tuning their retention strategies to help their organisation sustain their business.

\section{ACKNOWLEDGMENTS}

This research did not receive any specific grant from funding agencies in the public, commercial, or not-for-profit sectors. The authors thank all the eight informants for their sincere and valuable input during the interview session for the research. 


\section{REFERENCES}

Abubakar, R., Chauhan, A., \& Kura, K. (2014). Relationship between Perceived Organizational Politics, Organizational Trust, Human Resource Management Practices and Turnover Intention among Nigerian Nurses. Management Science Letters, 4(9), 2031-2048. doi: 10.5267/j.msl.2014.8.018

Afroz, N. N. (2018). Effects of training on employee performance-A study on the Banking sector, Tangail Bangladesh. Global Journal of Economics and Business, 4(1), 111-124.

Aguenza, B. B., \& Som A. P. M. (2012). Motivational Factors of Employee Retention and Engagement in Organisations. International Journal of Advances in Management and Economics, 1(6), 88-95.

Allen, D. G., Shore, L. M., \& Griffeth, R. W. (2003). The Role of Perceived Organizational Support and Supportive Human Resource Practices in the Turnover Process. Journal of Management, 29(1), 99-118. doi:10.1177/014920630302900107

AL-Muslawi, I. A., \& Hamid, A. A. (2019). External and internal factors affecting student's academic performance. The Social Sciences, 14 (4), 155-168. doi: 10.36478/sscience.2019.155.168

Azeez, S. A. (2017). Human Resource Management Practices and Employee Retention: A review of literature. Journal of Economics, Management and Trade, 18(2), 1- 10. doi:10.9734/JEMT/2017/32997

Baharin, N., \& Wan Hanafi, W., N. (2018). Effects of Talent Management on Employee Retention: A case of Hospitality Industry, Global Business and Management Research: An International Journal, 10(3), 697-707.

Banerjee, A. (2019). Failure of Employee Retention and Its Consequences on Organization Through Content Analysis. International Journal of Research - Granthaalayah, 7(3), 200-207. doi:10.5281/zenodo.2631378.

Beck, M. (2005). Exceptional leadership inspires the best efforts in others. Retrieved September 27, 2005, from http://www.barrelpublishing.com/articles/exceptional leadership inspires the best effort in others, shtml

Bergmann, T. J. \& Scarpello, V. G. (2001) Compensation Decision Making (4th ed.). Harcourt, Fort Worth, TX. 
Cennamo, L., \& Gardner, D. (2011). Generational differences in work values, outcomes and person-organisation values fit. IEEE Engineering Management Review, 39(2), 24-36, doi: 10.1109/EMR.2011.5876170

Chepkosgey, C. S., Namusonge, G. S., \& Makokha, E. N. (2019). Training Practice, a Perspective of Employee Retention in Firms. International Journal of Academic Research in Business and Social Sciences, 9(7), 495-509. doi: 10.6007/IJARBSS/v9-i7/6141

Cropanzano, R., \& Mitchell, M. S. (2005). Social Exchange Theory: An interdisciplinary review. Journal of Management, 31(6), 874-900. doi: 10.1177/0149206305279602

Das, B. L., \& Baruah, D. (2013). Employee Retention: A review of literature. IOSR Journal of Business and Management, 14(2), 8-16. doi:10.9790/487X-1420816

De Hauw, S., \& De Vos, A. (2010). Millennials' career perspective and psychological contract expectations: does the recession lead to lowered expectations? Journal of Business and Psychology, 25(2), 293-302. doi: 10.1007/s10869-010-9162-9

Dwomoh, G., \& Frempong E. O. (2017) Factors Influencing Employees' Retention in the Banking Industry of Ghana. Review of Public Administration and Management, 5(3), 1-7. doi:10.4172/2315-7844.1000223

Eisenberger, R., Stinglhamber, F., Vandenberghe, C., Sucharski, I. L., \& Rhoades, L. (2002). Perceived Supervisor Support: Contributions to Perceived Organizational Support and Employee Retention. Journal of Applied Psychology, 87(3), 565. doi: 10.1037/0021-9010.87.3.565

Fadilah, P., Maniam, K., \& Nafis, A. (2015). Assessing gen Y impact on organisational performance: An analysis from the top management perspective. Journal of Administrative Science, 12(1), 47-59.

Falahat, M., Gee, S.K., \& Liew, C.M. (2019). A Model for Turnover Intention: Banking industry in Malaysia. Asian Academy of Management Journal, 24(2), 79-91. doi:10.21315/aamj2019.24. s2.6

Gharib, M.N., Kahwaji, A.T., \& Elrasheed, M.O. (2017). Factors Affecting Staff Retention Strategies Used in Private Syrian Companies During the Crisis. International Review of Management and Marketing. 7(2), 202-206.

Gupta, V. (2019). Talent management dimensions and its relationship with Generation Y employee's intention to quit: an Indian hotel perspective. International Journal of Tourism Cities, 6(3), 583-600. doi: 10.1108/IJTC-02-2019-0018 
Hafiza, N. S., Shah, S. S., Jamsheed, H., \& Zaman, K. (2011). Relationship between rewards and employee's motivation in the non-profit organisations of Pakistan. Business Intelligence Journal, $4(2), 327-334$.

Hassan, M., Jambulingam, M., Alam, M. N., \& Islam, S. (2019). Redesigning the retention strategy against the emerging turnover of generation Y: revisiting the long-standing problems from the 20th to 21st century. International Journal of Entrepreneurship, 23(2), 1-16. doi: $10.1177 / 0972150920926966$

Hurst, J. L., \& Good, K. (2009). Generation Y and career choice. Career Development International, 14(6), 570-593. doi: 10.1108/13620430910997303

Idris, A. (2014). Flexible working as an employee retention strategy in developing countries: Malaysian bank managers speak. Journal of Management Research, 14(2), 71.

Irshad, M., \& Afridi, F. (2007). Factors Affecting Employees Retention: Evidence from literature. Abasyn Journal of Social Sciences, 4(2), 307-339.

Kalali, N. S. (2015). A Fuzzy Inference System for Supporting the Retention Strategies of Human Capital. Procedia - Social and Behavioral Sciences, 207, 344- 353. doi:10.1016/j.sbspro.2015.10.104

Kaliannan, M., Abraham, M., \& Ponnusamy, V. (2016). Effective talent management in Malaysian SMEs: A proposed framework. The Journal of Developing Areas, 50(5), 393-401.

Karve, S., \& Dias, M. S. (2016). HRM practices and retention of employees in the hotel industry in South Mumbai. International Journal of Multidisciplinary Approach and Studies, 3(3), 13-19.

Kossivi, B., Xu, M., \& Kalgora, B. (2016). Study on Determining Factors of Employee Retention. Open Journal of Social Sciences, 4(5), 261-268. doi:10.4236/jss.2016.45029

Lavanya, B. L. (2017). A Study on Employee Attrition: Inevitable yet Manageable. International Journal of Business and Management Invention, 6(9), 38-50.

Lee, Y., \& Sabharwal, M. (2014). Education-Job Match, Salary, and Job Satisfaction Across the Public, Non-Profit, and For-Profit Sectors: Survey of recent college graduates. Public Management Review, 18(1), 40-64. doi:10.1080/14719037.2014.957342 
Lobburi, P. (2011). The Influence of Organisational and Social Support on Turnover Intention in Collectivist Contexts. Journal of Applied Business Research, 28(1), 93-104. doi:10.19030/jabr.v28i1.6687

Luscombe, J., Lewis, I., \& Biggs, H. C. (2013). Essential Elements for Recruitment and Retention: Generation Y. Education and Training, 55(3), 272-290. doi:10.1108/00400911311309323

Mahadi, N., Woo, N. M. F., Baskaran, S., \& Yaakop, A. Y. (2020). Determinant Factors for Employee Retention: Should I Stay? International Journal of Academic Research in Business and Social Sciences, 10(4), 201-213. doi: 10.6007/IJARBSS/v10-i4/7120

Majid, M. A. A., Samsudin, A., Noorkhizan, M. H. I., Noor, S. N. A. M., \& Zuffri, N. S. H. A. (2017). Career Development, Job Security and Employee Loyalty at a Luxury Resort in Terengganu, Malaysia. International Journal of Academic Research in Business and Social Sciences, 7(10), 667-674. doi: 10.6007/IJARBSS/v7-i10/3422

Mamun, C. A., \& Hasan, M. N. (2017). Factors Affecting Employee Turnover and Sound Retention Strategies. Problems and Perspectives in Management, 15(1), 63-71. doi:10.21511/ppm.15(1).2017.06

Mbugua, G. M., Waiganjo, E. W., \& Njeru, A. (2015). Relationship between Strategic Performance Management and Employee Retention in Commercial Banks in Kenya. International Journal of Business Administration, 6(1), 53-62. doi:10.5430/ijba.v6n1p53

Meuse, K. P., \& Mlodzik, K. J. (2010). A second look at generational differences in the workforce: Implications for HR and talent management. People and Strategy, 33(2), 50-58.

Mngomezulu, N., Challenor, M., Munapo, E., Mashau, P., \& Chikandiwa, C. (2015). The impact of recognition on retention of good talent in the workforce. Journal of Governance and Regulation, 4(4), 372-379. doi: 10.22495/jgr_v4_i4_c3_p2

Naim, M. F., \& Lenka, U. (2018). Development and retention of Generation Y employees: a conceptual framework. Employee Relations, 40 (2). 433-455. doi: 10.1108/ER-09-2016-017

Nawaz, M., \& Pangil, F. (2016). The Relationship between Human Resource Development Factors, Career Growth and Turnover Intention: The mediating role of organisational commitment. Management Science Letters, 6,157-176. doi:10.5267/j.msl.2015.12.006

Pittino, D., Visintin, F., Lenger, T., \& Sternad, D. (2016). Are High-Performance Work Practices Really Necessary in Family SMEs? An Analysis of the Impact on Employee Retention. Journal of Family Business Strategy, 7(2), 75-89. doi:10.1016/j.jfbs.2016.04.002 
Puspanathan, C. A., Ramendran, C., Muthurajan, P., \& Singh, N. B. (2017). Perceptions of Generation Y Undergraduate Students on Career Choices and Employment Leadership: A Study on Private Higher Education Institutions in Selangor. Malaysian Online Journal of Educational Sciences, 5(3), 46-59.

Rani, N., \& Samuel, A. (2016). A study on generational differences in work values and person organisation fit and its effect on turnover intention of Generation $\mathrm{Y}$ in India. Management Research Review, 39(12), 1695-1719.

Rice, E. (2005). The evolving role of the $\mathrm{hr}$ executive. Retrieved April 9, 2006, from http://www.innovativeemploveesolutions.com/knowledge/articles 04/article 45 strategic HR.html

Roy, B. (2018). Factors Determining Employee Retention: A Study in Banks. International Journal of Management Studies, V (Special Issue 2), 101. doi:10.18843/ijms/v5is2/13

Queiri, A., \& Dwaikat, N. (2016). Factors affecting Generation Y employees' intention to quit in Malaysian's business process outsourcing sector. Journal of Sustainable Development, 9(2), 78. doi: $10.5539 /$ jsd.v9n2p78

Queiri, A., Yusoff, W. F. W., \& Dwaikat, N. (2015). Explaining Generation-Y employees' turnover in the Malaysian context. Asian Social Science, 11(10), 126. doi: 0.5539/ass.v11n10p126

Shih, W., \& Allen, M. (2007). Working with Generation-D: adopting and adapting to cultural learning and change. Library Management, 28 (1/2), 89-100. doi: 10.1108/01435120710723572

Simoneaux, S., \& Stroud, C. (2010). Bridging the generation gaps in the retirement services workplace. Journal of Pension Benefits, 17 (2), 66-75.

Stirpe, L., \& Zárraga-Oberty, C. (2017). Are High-Performance Work Systems Always a Valuable Retention Tool? The Roles of Workforce Feminization and Flexible Work Arrangements. European Management Journal, 35(1), 128-136. doi:10.1016/j.emj.2016.04.002

Wiggins, J. E. (2016). Exploring Generation Y Leaders' Motivation and Retention Within the ServiceIndustry. Walden Dissertations and Doctoral Studies. Retrieved from https://scholarworks.waldenu.edu/cgi/viewcontent.cgi $?$ article=4116\&context=dissertations

Wikhamn, W., \& Hall, A. T. (2012). Social Exchange in a Swedish Work Environment. International Journal of Business and Social Science, 3(23), 56-64. 
Younas, M., \& Waseem Bari, M. (2020). The relationship between talent management practices and retention of generation 'Employees: the mediating role of competency development. Economic research-Ekonomska istraživanja, 33(1), 1330-1353. doi: 10.1080/1331677X.2020.1748510

Zainee, I. A., \& Puteh, F. (2020). Corporate social responsibility impact on talent retention among Generation Y. Revista de Gestão, 27 (4), 369-392. doi: 10.1108/REGE-06-2019-0070

Zee, N. Y., \& Yuk, F. C. (2016). Issues and Challenges Faced by Generation X While Managing Generation Y. International Journal of Business and Social Science, 7(2), 167-170. 